\title{
Cost, Returns and Profitability of Ber Production in Solapur District of Maharashtra, India
}

\author{
M.S. Bhong, S.R. Nagargoje and R.D. Shelke* \\ Department of Agricultural Economics, College of Agriculture, Latur, India \\ *Corresponding author
}

\section{A B S T R A C T}

\begin{tabular}{|l|}
\hline Ke y w o r d s \\
Ber, Cost, Gross \\
return, Net profit, \\
B:C ratio and \\
Sampling design \\
\hline Article Info \\
\hline $\begin{array}{l}\text { Accepted: } \\
\text { 20 April } 2019 \\
\text { Available Online: } \\
\text { 10 May } 2019\end{array}$ \\
\hline
\end{tabular}

\section{Introduction}

Ber is native of India. It is believed that the Indo-Malaysia region (South and South-east Asia) is the centre of both evolution and distribution of the genus Ziziphus. The major production area of ber is in the semiarid and arid parts of the country. It is widely cultivated in Punjab, Haryana, and Maharashtra. Eighteen species are found in the Indian subcontinent from the Himalayas to Capecamorin and from the Western region to the Eastern wet tropics. The increase demand may lead to increase in prices of ber and farmers may be benefited. The need was felt to answer some queries such as cost, returns and profitability. Keeping in view of the above aspects, the present study was undertaken. The major production area of ber is in the semiarid and arid part of the country.

The total area under ber in India during 20172018 reported to be 49 thousand hectors \& production is about 530000 million tonnes. (Source: Indiastat.com). In Maharashtra area under ber cultivation is 0.99 thousand hectare with the production of 12.26 thousand metric tonnes in 2017-18. (Source: Indiastat.com) and the Area, Production and Productivity of Ber in Solapur district is 7461 ha, 37,10,000 Qtl, 50 Qt1/hectors respectively. (Source: kvkSolapur.org.) 
The main objectives of this study to estimate costs and returns in ber production.

\section{Materials and Methods}

Multistage sampling design was adopted for selection of the district, telsil, village and ber growers. In first stage, Solapur district was purposively selected on the basis of highest area under ber crop. In the second stage, Pandharpur and Sangola tehsils were selected on the basis of highest area under ber crop. In the third stage, 6 villages were selected from each selected tehsils. In the fourth stage, from each of the selected villages, 8 ber growers were randomly selected. In this way 96 ber growers were selected for the present study. Data were collected with the help of presented schedule by personal interview method for the year 2017-2018. Data were converted to per hectare basis in tabular form; statistical tools like arithmetic mean, percentage and ratio were used for accounting the cost and returns in ber production.

The cost concept like Cost $-\mathrm{A}$, Cost $-\mathrm{B}$, and Cost $-\mathrm{C}$ were used for cost evaluation and to estimate profitability in ber production. Cost A include the item namely, hired human labour, bullock labour, machine labour, manure, fertilizer, plant protection, irrigation, land revenue, incidental charges, interest on working capital and depreciation on assets. Cost-B comprises of the cost-A plus Amortized establishment cost, rental value of land and interest on fixed capital. Cost-C includes the cost-B plus family labour cost. The terms and concepts used in present study were as fallows. Interest on working capital included by charging interest at the rate of 13 per cent items of expenditure as hired human labour, bullock labour, machine labour, seed, fertilizers, manures, plant protection, land revenue an incidental charges for crop duration. Depreciation is the decrease in the value of asset and 10 per cent on the present value at the beginning of the year of farm implements and machinery was taken and only the proportionate charges were taken for the estimate as $1 / 6^{\text {th }}$ the value of gross produce that is value of main product plus value of by product minus land revenue. Interest on fixed capital by charging interest at the rate of 11 per cent on investment on commonly used assets like wooden implements, iron implements which were distributed on cropped area.

\section{Result and Discussion}

\section{Per hectare physical inputs used and output obtained in ber production}

From the Table 1, it is revealed that at the overall level, the per hectare use of hired human labour were 40.49 man days. Per hectare use of family human labour were 56.60 man days. It is observed that, utilization of bullock labour per hectare were 2.97 pair days. On the contrary, machine labour was used as 16.42 hours on the ber farm. On an average utilization of manures per hectare was found to be 55.22quintals. Average use of nitrogen, phosphorus and potash fertilizer was $110.48 \mathrm{~kg}, 55.48 \mathrm{~kg}$ and $110 \mathrm{~kg}$ per hectare at overall level, respectively.

\section{Per hectare annual cost of ber cultivation}

Per hectare cost of cultivation of ber was studied and depicted in Table 2. The per hectare cost of cultivation was Rs. 154772.67 in which Cost-A consist (38.01\%) and CostB (83.54 \%) i.e. Rs. 58839.21 and Rs. 129298.72 respectively. Expenditure on rental value of land ranks first Rs.52677.86 i.e. $(34.03 \%)$. 
Table.1 Per hectare physical inputs in ber production on the sample farm

\begin{tabular}{|c|c|c|c|}
\hline Sr.No. & Particulars & Unit & Quantity \\
\hline \multicolumn{4}{|c|}{ INPUTS } \\
\hline 1 & Hired Labour & Man day & 40.49 \\
\hline 2 & Bullock Labour & Pair day & 2.97 \\
\hline 3 & Machine Labour & Hour & 16.42 \\
\hline 4 & Manure & Qtl & 55.22 \\
\hline \multirow[t]{4}{*}{5} & Fertilizers & $\mathrm{Kg}$ & \\
\hline & Nitrogen & & 110.48 \\
\hline & Phosphorous & & 55.47 \\
\hline & potassium & & 110 \\
\hline 6 & Family Labour & Man day & 56.60 \\
\hline \multirow[t]{2}{*}{7} & OUTPUT & & \\
\hline & Main produce & qtl & 221.73 \\
\hline
\end{tabular}

Table.2 Per hectare annual cost of ber cultivation

\begin{tabular}{|c|c|c|c|c|}
\hline Sr.No & Particular & Quantity & Amount (Rs./ha) & Per cent \\
\hline 1 & Hired human labour & 40.49 & 18010.41 & 11.63 \\
\hline 2 & Bullock Pair & 2.97 & 2079.00 & 1.34 \\
\hline 3 & Machine labour & 16.42 & 6568.00 & 4.24 \\
\hline 4 & Manure & 55.22 & 11045.37 & 7.13 \\
\hline \multirow[t]{4}{*}{5} & Fertilizers & & & \\
\hline & Nitrogen & 110.48 & 1436.24 & 0.92 \\
\hline & Phosphorus & 55.47 & 1385.06 & 0.89 \\
\hline & Potassium & 55.74 & 1053.93 & 0.68 \\
\hline 6 & Irrigation & & 1500.00 & 0.96 \\
\hline 7 & Plant protection charges & & 2576.38 & 1.66 \\
\hline 8 & Incidental Charges & & 551.59 & 0.35 \\
\hline 9 & Repairs & & 450.00 & 0.29 \\
\hline 10 & Interest on working capital @13\% & & 11070.03 & 7.15 \\
\hline 11 & Depreciation on capital assets @ $10 \%$ & & 987.74 & 0.63 \\
\hline 12 & Land revenue and other taxes & & 125.46 & 0.08 \\
\hline 13 & Cost -A ( $\Sigma$ item 1 to 12$)$ & & 58839.21 & 38.01 \\
\hline 14 & Amortized establishment cost & & 12342.68 & 7.97 \\
\hline 15 & Rental value of land & & 52677.86 & 34.03 \\
\hline 16 & Interest on fixed capital @ $11 \%$ & & 5438.97 & 3.51 \\
\hline 17 & Cost-B ( $\Sigma$ item 13 to 16$)$ & & 129298.72 & 83.54 \\
\hline 18 & Family labour (man days) & 56.60 & 25473.95 & 16.45 \\
\hline 19 & Cost $-\mathrm{C}$ ( $\Sigma$ item 17 to 18$)$ & & 154772.67 & 100 \\
\hline
\end{tabular}


Table.3 Per hectare costs and returns from ber cultivation (Rs/ha)

\begin{tabular}{|l|l|c|}
\hline Sr.No. & Particular & Ber \\
\hline $\mathbf{1}$ & Gross returns & 316217.19 \\
\hline $\mathbf{2}$ & Cost-A & 58839.21 \\
\hline $\mathbf{3}$ & Cost-B & 129298.72 \\
\hline $\mathbf{4}$ & Cost-C & 154772.6 \\
\hline $\mathbf{5}$ & Farm business income (Gross return minus cost-A) & 257377.98 \\
\hline $\mathbf{6}$ & Family labour income (Gross return minus cost-B) & 186918.47 \\
\hline $\mathbf{7}$ & Net profit (Gross return minus cost-C) & 161444.59 \\
\hline $\mathbf{8}$ & Output-Input ratio & 2.04 \\
\hline $\mathbf{9}$ & Per quintal cost of production & 698.02 \\
\hline
\end{tabular}

Next item of expenditure is family labour accounted Rs.25473.95 (16.45 \%), hired human labour Rs.18010.41 (11.63 \%), Amortized establishment cost 11559.77 (7.05\%), interest on working capital Rs.11070.03(7.15 \%), Manure 11045.37 (7.13 \%), machine labour accounted Rs. 6568.00 (4.24 \%), interest on fixed capital Rs.5438.97 (3.51\%), fertilizer i.e. Rs.3875.23 (2.49\%), plant protection accounted Rs.2576.38 (1.66 \%), irrigation charges Rs.1500 (0.96 \%), bullock labour Rs.2079 (1.34\%), depreciation on farm assets Rs.987.74 (0.63 \%), repairs Rs.450.00 (0.29\%), incidental charges Rs.551.59 (0.35\%), and land revenue and other taxes Rs. $125.46(0.08 \%)$. As the size of holding increases family labour shows decreasing trend.

From table 3, it was observed that the gross return was Rs. 316217.19. It was clear that per hectare farm business income, family labour income and net profit was Rs.257377.98, Rs. 186918.47 and Rs. 161444.59 respectively in ber garden. The Output-Input ratio was higher as 2.04 in ber orchard. Per quintal cost of production was Rs.698.02.

It is concluded that output- input ratio of ber was 1.74 which showed that ber fruit was found to be profitable venture in Solapur district.

\section{References}

Baksh, K., Ishtiaq, H. and Muhammad, S.A. (2006) Profitability and Cost in Growing Mango Orchard. Journal of Agriculture and Social Sciences, 2(1):46-50.

Rajashekar and Kumar, D. (2017) Cost and return of ginger in Bidar district of Karnataka an economic analysis. Journal of Pharmacognosy and Phytochemist, 6(5):472-475.

Shennewad, B.A. and Shelke, R.D. (2008) Costs and returns in papaya production in Marathwada region of Maharashtra state. International Journal of Commerce and Business Management, 5(2):55-58.

Surwase, R.V., Kshirsagar, P.J., Talathi, J.M. and Gore, S.T. (2015) Costs, returns and profitability of sapota in Thane district. International Research Journal of Agricultural Economics and Statistics, 6(1):96-99.

Thorat, M.V. and Shelke, R.D. (2012) Economics of Ber Production in Beed District of Maharashtra. International Journal of Commerce and Business Management, 5(2): 207-209.

\section{How to cite this article:}

Bhong, M.S., S.R. Nagargoje and Shelke, R.D. 2019. Cost, Returns and Profitability of Ber Production in Solapur District of Maharashtra. Int.J.Curr.Microbiol.App.Sci. 8(05): 2464-2467. doi: https://doi.org/10.20546/ijcmas.2019.805.290 